\title{
O ENCANTO DA MÚSICA E A MÚSICA ENCANTADA: ENSAIO SOBRE MÚSICA E SOCIEDADE*
}

Hermes Soares dos Santos**

RESUMO

Neste artigo, o autor pretende mostrar como o mito da racionalidade foi construído pelo sujeito moderno, ilustrado pela figura de Ulisses, herói mítico que destruiu o ciclope Polifemo. Esse mito racional faz-se presente na indústria cultural, principalmente nas obras musicais. O autor aponta a nova música como alternativa para uma concepção estética que contenha a diferença não rentável de valores e caracteres que a indústria cultural desconhece e marginaliza.

Palavras-chave: mito da racionalidade, sujeito moderno, indústria cultural, nova música.

O UNIVERSO MITOLÓGICO E O UNIVERSO RACIONAL: MUNDOS DIFERENTES E IGUALMENTE ESCLARECIDOS E ENCANTADOS

"Toma, Ciclope; bebe vinho, após comeres carne humana, para saberes que bebida carregava nosso barco. Eu o trazia para fazer-te uma libação, se compadecido, me enviasses para a minha terra. Mas quem pode suportar a tua fúria? Desgraçado, como há de vir visitar-te doravante alguém da incontável Humanidade, se não te comportas como se deve?" Assim falei; ele tomou e bebeu. Gostou imensamente de sorver a suave bebida e pediu-me segunda vez: "Dá-me mais, de bom grado, e dize-me o teu nome em seguida, para eu te dar um presente de hospitalidade, que te alegre. [...]" Três vezes o trouxe e

\footnotetext{
* Artigo recebido em 17/08/2004 e aprovado em 20/09/2004.

** Frade franciscano; bacharel em flauta transversal pela UnB; Licenciado em Filosofia pelo IFITEG. [e-mail: menorhss@ @otmail.com]
} 
dei; três vezes ele bebeu como um louco. Quando o vinho subiu aos miolos do Ciclope, eu lhe dirigi palavras gentis: "Ciclope, perguntaste o meu glorioso nome; eu vou dizer-to; dá-me, porém, o presente, como prometeste. Meu nome é Ninguém. Chamam-me Ninguém minha mãe, meu pai e todos os meus companheiros." Assim falei e ele replicou-me prontamente, sem piedade na alma: "Será Ninguém o último que comerei. "Depois de seus camaradas; irão primeiro os outros; será esse o presente de hospitalidade.” (Homero, p. 108)

O trecho acima refere-se a um dos relatos da Odisséia analisado por Adorno e Horkheimer na obra Dialética do esclarecimento (1985, p. 56-80). Trata-se da persuasão de Ulisses feita ao terrível Polifemo, um gigante que possuía um só olho, um ciclope, filho de Posêidon e da ninfa Toosa. Sua audaciosa persuasão, regada pelo efeito entorpecedor do vinho, amansa o monstro e torna possível a conversa entre ambos. "Chamam-me Ninguém minha mãe, meu pai e todos os meus companheiros". Polifemo, não sabendo o que estava à sua espera, um golpe certeiro que lhe cegaria o único olho, promete devorar Ulisses, mesmo sem conhecer a sua proveniência, pois quem se denomina Ninguém oculta sua identidade e sua origem.

Em tempos mitológicos como o referido, o mito estava presente nas sociedades tradicionais mediante uma experiência carregada de símbolos. O interior do homem, amarrado a relações sociais cuja consciência era coletiva, guiava-se por relatos contados por ancestrais, nos quais uma forma intuitiva de compreensão do mundo e sua gênese expressava-se como pretensão de dominá-lo, pois suas manifestações eram muito assustadoras e desconhecidas em suas origens. ${ }^{1}$ (ARRUDA, p. 22-24). Esse domínio estendia-se a toda comunidade, na qual encontravam-se padrões comportamentais gerados por uma visão específica de mundo. A compreensão da realidade universal estava ligada a um jogo de múltiplas relações entre o homem, a natureza e os deuses, e esses elementos oníricos e fantasiosos eram atualizados e eternizados nos símbolos:

Os mitos, assim como os ritos mágicos, têm em vista a natureza que se repete. Ela é âmago do simbólico: um ser ou um processo representado como eterno porque deve voltar sempre a ocorrer na efetuação do símbolo. Inexauribilidade, renovação infinita, permanência do significado não são atributos de todos os símbolos, mas seu verdadeiro conteúdo. (Adorno; Horkheimer, 1985, p. 30-31) 
O contexto da Odisséia estava imerso nessa atmosfera sacralizada, repleta de desconexões e lacunas susceptíveis a muitas interpretações, ${ }^{2}$ pois os fatos mitológicos não se sucedem dentro de uma lógica científica ou racional. Há também nesse contexto "o engendramento de circunstâncias que dependem do homem e o de outras diante das quais ele nada pode" (MAтоs, 1997, p. 30). Dentro do conjunto das possibilidades nas quais o homem podia interferir, surgem a figura de Ulisses e de seus companheiros, que desafiavam a interferência dos mitos na trajetória de suas aventuras.

Há no conteúdo dessas aventuras o nascimento de uma unidade distinta da universalidade que a cerca. Quando a augusta Circe ensina Ulisses como proceder com sua tripulação durante a viagem que passaria pela ilha das Sereias, entidades cujo maravilhoso canto levava ao naufrágio toda embarcação que por ali navegava, alerta-o com o seguinte conselho: "Depois que teus companheiros tiverem remado para além delas, daí já não te posso dizer a seguir qual de dois caminhos será o teu; tu mesmo deves decidir a escolha" (Homero, p. 142). A capacidade de escolher é própria desse sujeito-líder destruidor de sistemas rigidamente estruturados e construtor de outras estruturas que também culminam em rígidos sistemas.

Ulisses, um homem a mais submerso na universalidade fechada dos mitos e movido pelo destino, é despertado pelo ideal de enfrentar as ameaças de quem desafia tão densa estrutura. Ele é o símbolo do sujeito moderno que, ao contrário do homem primitivo, do filósofo grego e do medievo, está cansado de procurar a compreensão da natureza das coisas em teogonias, cosmogonias ou cosmologias, pois as julga limitadas para responder às perguntas angustiadas da existência. Lança-se então, na escuridão melancólica e vertiginosa do caos desestruturador de conceitos, pensamentos, princípios e paradigmas. Ao denominar-se "Ninguém", ele já é o produto de sua própria busca e método. Transforma-se nas medidas orientadoras da navegação. Ele é a descendência do desejo de muitos heróis, os quais, antes dele, abriram caminho em trajetos desconhecidos e influenciaram novas gerações com seu idealismo positivista, ${ }^{3}$ que deseja ter poder sobre tudo. Ele é o Ninguém, fruto de seu próprio esclarecimento. ${ }^{4}$

No sentido mais amplo do progresso do pensamento, o esclarecimento tem perseguido sempre o objetivo de livrar os homens do medo e de 
investi-los na posição de senhores. Mas a terra totalmente esclarecida resplandece sob o signo de uma calamidade triunfal. O programa do esclarecimento era o desencantamento do mundo. Sua meta era dissolver os mitos e substituir a imaginação pelo saber. (...) Sem a menor consideração consigo mesmo, o esclarecimento eliminou com seu cautério o último resto de sua própria autoconsciência. Só o pensamento que se faz violência a si mesmo é suficientemente duro para destruir os mitos. (AdORNO; HorKHEIMER, 1985, p. 19-20)

Ulisses, ou melhor, Ninguém, é escolhido por Adorno e Horkheimer como o modelo desse pensamento racional e calculista que faz violência a si mesmo para construir um mundo perfeito. Ele é o imperialismo dos axiomas da razão científica que submete todos os outros aspectos da estrutura humana, como a emoção, a intuição, a imaginação, a fisiologia humana, mantidos em estado de constante mobilização para a defesa de um universo estável (MARCUSE, 1968). Esse imperialismo manipula todos esses aspectos por meio da ideologia de uma cultura industrial e do consumo de seus produtos, onde impera uma confortável, razoável e democrática pseudoliberdade.

O ciclope Polifemo, por sua vez, é semelhante ao consumidor da civilização atual que, mesmo sem conhecer a gênese do produto industrial moderno, consome-o assim mesmo. Assim, ele assume a falsa verdade da cultura de massa, que exige a renúncia de sua autenticidade potencialmente criativa, em troca de um lugar na passarela do prazer e do reconhecimento social. Esse comportamento é semelhante ao do homem primitivo, que temia fugir dos padrões comportamentais da sua comunidade, correndo o risco de ser estigmatizado por ela.

Apesar de ter sido advertido pelo adivinho de nome Télemo, Polifemo não resistiu ao poder da persuasão, nem percebeu a enganação. Respondeu, então, a seus outros amigos ciclopes, que o encontraram urrando de dor, gritando que Ninguém estava o matando por dolo e não pela força. Eles, sem nada entender, responderam que se ninguém o estava maltratando e ele estava só, não havia como fugir à moléstia enviada pelo grande Zeus; disseram então, que rezasse, pois, a Posêidon. A influência de Ninguém, por ser invisível, é tão forte, que cega e adoece Polifemo antes de lhe roubar por completo a identidade. É como uma moléstia que submete consumidores e gigantes empresariais ao poder do capitalismo monopolista. 
Polifemo, humilhado pela desgraça e cegueira, rogou a Ulisses para que dele se aproximasse. Prometeu-lhe presentes como o pedido a Posêidon para que retornasse em paz para sua casa. A ingenuidade conduziu-o à incapacidade de reação e à passividade, características também presentes nos participantes e espectadores da moderna cultura de massa. $\mathrm{O}$ efeito produzido pela cultura de massa faz com que o espectador e consumidor acreditem em sua autonomia e liberdade, sendo que essas já são pré-construídas. É aí que se encontra a ilusão invisível desse efeito: todos consumidores são direcionados individualmente, sem portas ou janelas ao redor, como a mônada de Leibniz, ${ }^{5}$ para o mesmo ponto. $\mathrm{O}$ individualismo da sociedade não está na falta de comunicação, mas em uma comunicação que conduz os indivíduos ao mesmo ponto de interesse. Esse ponto é o gozo efêmero, imediato e pré-construído:

A intuição do efêmero e a evasão do tempo estão na base da crença no sagrado e na eternidade. O ephemérios e o ephêmeros ("o que dura um dia") buscam a divinização do tempo, processo no qual personagens históricos e acontecimentos se convertem em mito e arquétipo: os primeiros assimilam-se ao herói e os acontecimentos transformam-se em façanhas e ações exemplares. Isso significa instaurar a eternidade do tempo, instaurar um tempo primordial, o tempo anterior à passagem do tempo. Constitui outra maneira de expressar o estranhamento que acompanha a percepção do desaparecimento e da simultânea desestabilização da rotina do mundo, de início tão próximo e tranqüilizador. (MATоs, 1997, p. 37)

O espírito inseguro e errante do sujeito burguês encarcerou em uma compreensão arquetípica, semelhante à compreensão mitológica, a imediatez do gozo fugaz, fim da divisão estratificada do trabalho e do prazer. Esse espírito, que não suporta sua constante tristeza e angústia, fundamentais para o desenvolvimento de uma existência autêntica, confirma a majestade dessa imediatez, glorificando-a pelo louvor à eficácia tecnológica. A tecnologia é capaz de recriar instantes sempre novos e lucrativos de prazer imediato e superficial, gerando nos indivíduos a compulsão consumista. Portanto, a experiência coletiva e dogmática dos mitos divinos e sagrados, repleta de encantos e de mistérios, apenas muda sua roupagem e torna-se a experiência subjetiva dos mitos racionalistas e profanos, transformando a realidade por meio de equações e padrões de medida: 
O que não se submete ao critério da calculabilidade e da utilidade torna-se suspeito para o esclarecimento. A partir do momento em que ele pode se desenvolver sem a interferência da coerção externa, nada mais pode segurá-lo. [...] Cada resistência espiritual que ele encontra serve apenas para aumentar sua força. Isso se deve ao fato de que o esclarecimento ainda se reconhece a si mesmo nos próprios mitos. (ADORNO; HORKHEIMER, 1985, p. 21-22)

Freud fundamenta o surgimento da cultura no processo de aniquilamento da busca individual por gratificação, em função da necessária e inevitável construção de "princípios gerais de justiça, aos quais devem submeter-se todos os membros da sociedade" (MATOs, 1986, p. 140). O progresso científico e industrial, fruto do desenvolvimento racional, um dos fatores responsáveis pela qualidade de todas as formas de vida no planeta Terra, construiu uma cultura cujo objetivo principal e radical é a obtenção do capital.

Para garantir essa obtenção, a manifestação dos impulsos eróticos, quando não anulada, é direcionada e aprisionada em um arquétipo de prazer imediato calculado, aceito socialmente e eternizado em ídolos famosos que comunicam sucesso e poder. O princípio do prazer é transformado em princípio da realidade reificada, por meio do qual a harmonia social torna-se possível mediante o domínio do interior do ser humano, libertando-o da ameaça destruidora do Eros incontrolado, tido como o precursor da barbárie (REALE, v. III, p. 851-852). "O indivíduo foi posto a serviço da Totalidade, bem como suas paixões, para que se realizasse 'A razão na história'. E o homem tornou-se disponível para a ciência realizar seus próprios fins egóicos. Nada a limita” (MAтоs, 1986, p. 148).

O modelo do homem moderno civilizado é mitificado pela indústria cultural e transforma-se em um modelo universal e totalitário que aniquila aspectos particulares e individuais. A sociedade moderna realiza então uma falsa experiência social (CoHn, 1986, p. 11-12). Cada aspecto particular da sociedade é o retrato de um sistema no qual impera o princípio da equivalência presente no valor de troca do mercado:

O cinema, o rádio e as revistas constituem um sistema. Cada setor é coerente em si mesmo e todos o são em conjunto. Até mesmo as manifestações estéticas de tendências políticas opostas entoam o mesmo louvor do ritmo de aço. [...] Os projetos de urbanização que, 
em pequenos apartamentos higiênicos, destinam-se a perpetuar o indivíduo como se ele fosse independente, submetem-no ainda mais profundamente a seu adversário, o poder absoluto do capital. [...] Sob o poder do monopólio, toda cultura de massa é idêntica, e seu esqueleto, a ossatura conceitual fabricada por aquele, começa a se delinear. Os dirigentes não estão mais sequer muito interessados em encobri-lo, seu poder se fortalece quanto mais brutalmente ele se confessa de público. (Adorno; HorKHEIMER, 1985, p. 114-115)

A FUNÇÃO DA PRODUÇÃO MUSICAL COMERCIAL: CONFIRMAÇÃO DO PERFIL SOCIAL REIFICADO

O objetivo do imaginário cultural moderno é criar uma identidade abstrata, constituída de elementos estéticos que promovem socialmente aqueles que consomem os produtos vendidos nas sociedades industriais, solidificando a harmonia racional e social fetichizada. Essa identidade estava presente na nova ordem que se estabeleceu entre Polifemo e Ulisses e no inevitável fim ao qual foram conduzidos: a aniquilação do mais fraco. A imediatez e o espírito da sociedade pré-burguesa se identificaram por meio da linguagem e seus recursos, tornando-a também um recurso, utilizado nas atividades comerciais, influenciando profundamente o espírito das obras culturais, principalmente as musicais, eliminando dessas o que não possuía força rentável.

No início do século XVII, provavelmente a tonalidade, estrutura de organização dos sons conhecidos como notas musicais, tornou-se o único universo musical estruturado a ser reconhecido pela audição. Esse processo, porém, foi involuntário. A tonalidade ajustava-se ao espírito objetivo da sociedade pré-burguesa e feudal. "Ela faz a mediação entre uma linguagem musical mais ou menos espontânea dos homens, uma linguagem, por assim dizer, falada, imediata, e normas que haviam se cristalizado dentro dessa linguagem" (ADORNo, 1968). Os chamados tons maior e menor, que constituem a tonalidade, são os modos litúrgicos jônio e eólio, contidos no conjunto dos sete modos litúrgicos: ${ }^{6}$ jônio, dório, frígio, lídio, mixolídio, eólio e lócrio. Modos como lídio e mixolídio orientam ainda a criação de melodias nordestinas regionais brasileiras, como a tradicional e folclórica "Eu vou falar pra vocês, como se dançam um baião"; peças para canto coral como "Sabiá, coração de uma viola", de 
Ayrton Escobar, e outros cantos e hinos religiosos do catolicismo popular nordestino.

A tonalidade constituiu-se na linguagem musical do Ocidente, transformando-se em uma segunda natureza da música (AdDRNo, 1968). Contudo, ela é utilizada de forma criativa por expressões artísticas que tentaram ser autênticas e criativas. É o caso de Beethoven. Em estruturas musicais complexas, como a Quinta Sinfonia, ela funciona como um jogo de montar. As peças, ou notas, presas à estrutura da tonalidade, são remanejadas dentro dos movimentos estilísticos já culturalmente conhecidos:

O esquema clássico do minuetto exigia que se apresentasse primeiramente o tema principal, depois a introdução de uma segunda parte, que pode levar a regiões tonais mais distantes - formalmente similar, por certo, à "ponte" (parte intermediária) na música popular de hoje - e, finalmente, a reapresentação da parte original. Tudo isso ocorre em Beethoven. Ele retoma a idéia do dualismo temático dentro da parte do scherzo, ao mesmo tempo que força aquilo que era, no minuetto convencional, uma regra de jogo tácita e sem sentido a falar com sentido. Ele alcança plena consistência entre a estrutura formal e o seu conteúdo específico, isto é, a elaboração de seus temas. Toda a parte scherzo desse scherzo (vale dizer, aquilo que ocorre antes da entrada das cordas graves em dó maior, que marca o início do trio) consiste no dualismo de dois temas, a figura arrastada nas cordas e resposta "objetiva", pétrea, dos instrumentos de sopro. Esse dualismo não é desenvolvido de maneira esquemática, de tal modo que primeiro seja elaborada a frase das cordas, depois a resposta dos instrumentos de sopro, para, então, o tema das cordas ser mecanicamente repetido. (AdORNO; SimpSON, 1941)

Algumas características presentes na música popular, ${ }^{7}$ apontadas por Adorno, como estandardização, pseudo-individuação, "glamour" (presente na coexistência dos dois anteriores), identificação, recordação, cimento social e transferência psicológica da autoridade de reconhecimento para o objeto, são evidências do caráter linear e totalizador da cultura industrializada.

Ao analisar as duas esferas da música, a música séria e a música popular, Adorno define a primeira como um todo distinto de seus detalhes, assim como estes também são distintos do todo, apesar de contê-lo em suas microestruturas (Adorno, 1941). A música popular, no entanto, 
contém detalhes cujo sentido é sempre o mesmo, não importando a ordem de sua colocação. Todo o conjunto é homogêneo; cada parte esgota, em si mesma, o seu sentido; não há um desenvolvimento gradativo que construa o conteúdo histórico da obra. O padrão standard $^{8}$ possibilita o estabelecimento da ilusão nos compositores ao determinar que não existem modelos de formas determinantes nos quais a criatividade deve enquadrarse. Eles se crêem livres para imaginar e compor. Contudo, o que ocorre é a produção de reações já previstas em compositores e ouvintes. O hit parade, por exemplo, segue um modelo musical preexistente (ADORNo, 1941).

Outro caráter de destaque presente na música industrializada, ligada à estandardização, é a pseudo-individuação (Adorno, 1941). Por meio dela, os ouvintes crêem-se livres no ato de escolher os produtos estandardizados, construídos também por limites estabelecidos pela padronização que escondem uma pseudoliberdade. Em companhia a essa pseudoliberdade, há também a pseudo-atividade, existente em um ouvinte quando ouve a alguma música no rádio e acredita interagir na escolha de ter acesso ou não ao que está sendo transmitido só pelo fato de poder desligar o aparelho ou mudar de estação, bem como relegar a música como mero passatempo de suas atividades ou manipulá-la por meio do aparato técnico de transmissão, como o equalizador e o volume.

O glamour, presente na inter-relação entre estandardização e pseudo-individuação, atrofia e infantiliza a capacidade do ouvinte adulto de decifrar conteúdos culturais de maior profundidade estética e espiritual (Adorno,1941). Essa prévia "lapidação" das músicas de consumo constrói, na memória dos ouvintes, a identificação necessária e imediata com o que é ouvido no texto e na melodia de uma canção (ADORNo, 1941). Constrói também a conseqüente recordação (ADORNo, 1941), transparente em uma exclamação como: "Já ouvi isto antes em algum lugar... Isto faz parte de mim." As características musicais, portanto, estão perfeitamente sintonizadas com as características da idéia abstrata do prazer imediato. São, como esse, pré-construídas.

A produção musical, na indústria cultural, tem o papel de cimento social. (Adorno, 1941) Seu objetivo é adaptar os ouvidos ao ritmo do sistema vigente. Essa adaptação está presente quando os ouvintes acreditam na autonomia de seu gosto musical. Há em certos estilos, como o soul rock, o rock balade e o jazz rock, um jogo bem montado de variações de previsibilidade calculada presentes no ritmo e na harmonia. 
A função de cimento social da música insere o ouvinte na apreciação artística do senso comum e no mundo fantástico e encantado da moda e seus produtos, tranqüilizando-o diante do risco de não ser aceito e reconhecido pelo contingente social. Ser consumidor de uma grande empresa, como McDonald's; ouvir e comprar um "CD" contendo os últimos sucessos de Sandy e Junior são características típicas da transferência psicológica da autoridade de reconhecimento para o objeto (ADORNo, 1941). Esse proceder inconsciente é a fetichização da música, dos métodos racionais e das leis científicas e da técnica aplicados a ela. O desejo de pertencer a um todo uniforme e culturalmente aceitável transforma indivíduos e bens de consumo na fotocópia perfeita desse todo, do qual os primeiros tentam compulsivamente pertencer para protegerem-se do estigma marginal que ameaçava de modo semelhante os povos primitivos:

A maneira pela qual uma jovem aceita e se desincumbe do date obrigatório, a entonação no telefone e na mais familiar situação, a escolha das palavras na conversa, e até mesmo a vida interior organizada segundo os conceitos classificatórios da psicologia profunda vulgarizada, a tudo isso atesta a tentativa de fazer de si mesmo um aparelho eficiente e que corresponda, mesmo nos mais profundos impulsos instintivos, ao modelo apresentado pela indústria cultural. (ADORNo; HORKHEIMER, 1985, p. 156)

A compulsão consumista é a mantenedora da harmonia. E esta última encontra-se no impacto rítmico repetitivo das paradas de sucesso e na melosidade romântica e "barata" das músicas de amor e paixão do senso comum, como as expostas no mercado das atuais canções sertanejas. O ouvinte desses estilos libera sua energia sexual reprimida por meio de um objeto não erótico, que é a música. A música funciona, nesse caso, como dessexualização da sexualidade (CARONE, p. 15). Como a música serve como um preenchimento do desejo de ser feliz, desejo esse jamais atingido, a relação viciosa entre consumidor e produto se estabelece, pois o ser humano frustrado passa a perseguir a falsa promessa de realização integral vigente nos modelos da indústria cultural:

Essa promessa da obra de arte de instituir a verdade imprimindo a figura nas formas transmitidas pela sociedade é tão necessária quanto hipócrita. Ela coloca as formas reais do existente como algo absoluto, 
pretextando antecipar a satisfação nos derivados estéticos delas. Nessa medida, a pretensão da arte é sempre ao mesmo tempo ideologia. (AdORNo; HorKHEIMER, p. 122)

As características da música de uma cultura de massa citadas acima podem ser percebidas quando o rádio é ligado e a emissora mais ouvida pela população é sintonizada. Quando músicas pop são tocadas, o velho compasso 4/4, que caracteriza estilos como o rock, apresenta-se mais evidente por meio da percussão e da bateria, que possuem o mesmo timbre eletrônico, quando não programadas eletronicamente, como acontece na techno music. Teclados programados em seqüência, guitarras e instrumentos de sopro, que na maioria das vezes é o saxofone, tem também, na maioria das vezes, o mesmo timbre, além das vozes dos cantores que evocam sempre o mesmo tipo de fraseado musical ao se delongar em vogais como $a, i, o$, presentes nos finais das frases das músicas de conteúdo patético e romântico. Se no passado a maior parte das músicas tocadas era cantada em inglês, pois só a música pop estadunidense atendia às sensações de gozo imediato dos consumidores, hoje, não importa se o idioma utilizado é o inglês, o português, o italiano ou o espanhol. A estrutura musical pop e a sensação provocada por ela são sempre as mesmas.

A música erudita, como a música clássica de Beethoven, também não escapa à vulgarização. O último movimento da $9^{a}$ sinfonia, ou até mesmo parte dele, é colocado isoladamente do conjunto da obra em uma faixa de um CD que contém suas composições mais conhecidas, transformadas em sucessos e em mera mercadoria. Isso demonstra que a obra foi separada do contexto histórico e cultural em que foi gerada, cujo conhecimento faz-se necessário para a compreensão de seu conteúdo.

O ADVENTO DA NOVA MÚSICA: A COMPREENSÃO PARCIAL DA NATUREZA DA MÚSICA E A POSSIBILIDADE DE INOVAÇÃo CULTURAL MEDIANTE SUA APRECIAÇÃO.

Apesar da influência das sonoridades harmônicas, rítmicas e melódicas estadunidenses estarem presentes na música pop brasileira, bem como em sua transformação em produto de consumo, a cultura musical de massa brasileira é bastante heterogênea (CoELHo, p. 80-88). 
Isso significa que a padronização abstrata e homogênea da música pop estadunidense não conseguiu sufocar a variedade de expressões culturais de origem negra, branca e indígena e dos diversos estilos regionais brasileiros. Mesmo que uma idéia de folclore mundial seja transmitida via TV em tempos de globalização neoliberal desenfreada, cantigas de roda ainda são ensinadas em escolas de cidades do interior brasileiro e expressões como o bumba-meu-boi, catira e as canções que as acompanham são provas marcantes de que ainda existe soberania nacional. Claro que esses exemplos não impedem que essas expressões sejam adaptadas ao mercado televisivo e radiofônico, contudo, seus elementos característicos não são totalmente anulados.

Transportando a análise feita anteriormente entre indivíduo e cultura musical para dentro de um contexto mais amplo, ou seja, entre cultura musical particular e cultura musical universal, percebe-se que uma presença ainda mais marcante, não só no Brasil, mas em todo mundo, da força criadora que não se submete a modelos rentáveis. Essa força criadora está no advento da música nova. A nova música lança seu desafio trágico da subjetividade na realidade, rompendo com os limites, janelas e portas dos elementos músico-tonais, revelando que a procura de mundos sonoros novos provém do fastio dos mundos sonoros antigos:

Há concertos sinfônicos e de câmara em todas as grandes e em muitas pequenas cidades do mundo: mas sempre se nos oferece o mesmo repertório histórico, de Bach e Handel até Brahms e Debussy, a safra de menos de 200 anos. É ainda mais conservador o repertório das casas de ópera: de Gluck até Richard Strauss, e nada mais. O disco long-play ampliou grandemente o repertório acessível aos amigos da música. Mas é, outra vez, um repertório histórico, incluindo Monteverdi e Vivaldi, Couperin e Domenico Scarlatti. (CARPEAux, 1999, p. 389)

A nova música, paralelamente a outros movimentos e estilos artísticos, surge como protesto contra a vulgaridade da arte no final do século XIX, na Europa. Um de seus aspectos mais evocados é o atonalismo, rompendo com leis tonais e com o fetichismo musical. A cisão entre ela e a tonalidade é mais profunda e dual que a ruptura entre linguagem falada e linguagem literária. (ADORNo, 1941). Adorno, que era discípulo de Alban Berg, um dos divulgadores do dodecafonismo, ${ }^{9}$ descreve parte dessa nova estrutura musical: 
A nova música não tolera nem mais leis semelhantes à linguagem nem se equipara àquilo que a maioria dos homens escuta como que de um modo pré-artístico e infantil. Também a linguagem verbal falada e a literário-objetiva separaram-se; só que, na música, a ruptura é bem mais radical. A diferença entre a tonalidade e o material emancipado de hoje; o do sistema dos doze semitons equivalentes e bem temperados - tons de um quarto e um sexto podem ficar fora de cogitação - não está na distinção superficial entre um sistema, um esquema ordenador e outro, mas na distinção entre uma linguagem sedimentada, por um lado, e um processo que percorreu a vontade consciente da consciência emancipada, por outro. (ADORNO, 1941)

Essa inovação não aconteceu apenas na música, mas em toda manifestação artística. Depois das catástrofes mundiais nos campos político, econômico e social da primeira metade do século XX, não é mais possível fazer arte como se vivesse nos séculos anteriores (CARPEAUX, p. 340). A arte, até então, pertencia à realidade, e a realidade estava marcada pelo horror. ${ }^{10} \mathrm{O}$ horror foi produzido por personalidades autoritárias, de caráter manipulativo, fruto do mal-estar civilizado inibidor de libidos que, devido à total identificação do indivíduo com a divisão mecânica, objetiva e desumana do trabalho, identificaram-se de forma patológica com a tecnologia e projetaram toda sua fúria libidinosa reprimida sobre milhões de inocentes. A identificação com a tecnologia levou à falta de identificação dos indivíduos com eles mesmos, sendo essa característica fundamental, portanto, para que um genocídio, como Auschwitz, acontecesse:

No tipo que tende para a fetichização da tecnologia, trata-se, simplesmente, de pessoas incapazes de amar. Isso não tem uma conotação sentimental, nem tampouco moralizante, mas designa o insuficiente relacionamento libidinal com outras pessoas. [...] O que nelas ainda sobrevive da capacidade de amar, elas precisam usar em coisas materiais. Os caracteres preconceituosos, presos à autoridade, [...] fornecem numerosas evidências disso. Um voluntário [...] disse de si mesmo: "I like nice equipment" (Eu aprecio belos equipamentos), sejam quais forem eles. O seu amor foi absorvido por objetos, máquinas enfim. $\mathrm{O}$ que choca tanto nesse fato - e choca porque parece tão inútil combatê-lo - é que essa tendência está ligada à civilização inteira. (ADORNO, 1974) 
Na divisão mecânica do trabalho, as personalidades estão fragmentadas em id, ego e superego, ${ }^{11}$ com detrimento do segundo (MATos, p. 150). O primeiro, no qual se encontram todas as manifestações impulsivas e instintivas da energia psíquica humana, encontra-se acorrentado e castrado pela deformação do último pela indústria cultural. O poder do superego, no qual reside a consciência moral, encontra-se fortificado pelo poder do conhecimento cientificista e cristalizado no âmago das personalidades autoritárias como moralismo. O paraíso idealizado por ele não é um desejo de realização do ser, mas a frustração dos impulsos decepcionados.

Todavia, o inquieto desejo de saber, o inquieto Eros, foi libertado pela própria alienação produzida pela divisão do trabalho. "Quanto mais o indivíduo permanece estranho ao trabalho necessário, tanto menos é envolvido pelo reino da necessidade" (MARCUSE, 1968). Tendo o seu tempo livre ampliado pelo trabalho que atualmente é feito pelas máquinas, suas potencialidades explodem em sentimentos brutais e evocações eróticas não-convencionais e reprimidas. Essas manifestam um protesto explosivo e motor de um big-bang criativo, crítico e autocrítico, misterioso e enigmático, presente no labor de tantos músicos e outros tipos de artistas inconformados.

A politonalidade, a atonalidade e outras técnicas surgiram paralelamente ao abandono da perspectiva por pintores após Picasso e correspondem à mesma crise das ciências naturais que adotaram o relativismo. $\mathrm{O}$ retorno de estruturas musicais antigas corresponde aos anseios da arquitetura funcional. $\mathrm{O}$ renascimento de formas barrocas, pré-clássicas é contemporâneo do historicismo na sociologia e na filosofia. "A música nova não é capricho arbitrário de alguns esquisitões ou esnobes. É o reflexo verídico da realidade" (CARPEAUX, p. 340).

A música nova, portanto, não foi e ainda não é aceita nem divulgada em circuitos mais amplos. Igor Stravinsky (1882-1971), oriundo de Oranienbaum, perto de Petersburgo, Rússia, sentia essa angústia da arte contemporânea, cujo caos é semelhante ao da música barroca antes de Bach. Contrário ao nacionalismo musical russo e amante da obra de Tchaikovsky, seu desejo era organizá-la por meio, segundo ele mesmo, de um único caminho possível, que é a religião, e fazer uma síntese musical entre Oriente e Ocidente (CARPEAUX, p. 344-345). A sagração da primavera, de Stravinsky, foi exibida ao público pela primeira vez em Paris, em 29 de maio de 1913, no Théâtre des Champs-Elysées. Foi 
veementemente vaiada. O cenário "rezava" um verdadeiro culto à primavera, na qual a puberdade é venerada e sacrificada. De modo diferente das obras tradicionais, não existem interrupções entre os movimentos, além de possuir um motivo musical que surge do silêncio no início de cada movimento e encarna-se junto ao conjunto diferenciado e ímpar, criando um nexo tenso e surpreendente. Não existem detalhes aleatórios; todos são bem diferentes uns dos outros e todos estão em comunicação, pois possuem sentido:

\begin{abstract}
O furioso movimento polirrítmico das danças, as dissonâncias ásperas da escritura extremamente cromática e politonal parecem-lhes o retrato musical dos tempos novos, da nossa época das máquinas. Quase já não se percebe que a obra foi concebida como evocação dos tempos bárbaros da Rússia pré-cristã e pré-eslava, dos citas; que é uma obra de primitivismo produzida com os recursos do mais requintado intelectualismo. Parece ligada ao estado de espírito de 1913 que, às vésperas das grandes catástrofes, as pressentiu sem ainda temê-las, por falta de experiência. (CARPEAUX, 1999, p. 343)
\end{abstract}

No Brasil, o espírito da música nova fez-se evidente na pessoa e na obra de Heitor Villa-Lobos (1887-1959). A ele foi atribuída "a descoberta musical do Brasil". Sua inspiração de força vulcânica embasouse no folclore nacional e misturou-se a influências de Debussy, Stravinsky e Bach. Com essas influências pode-se denotar a presença de elementos da musicalidade folclórica brasileira, o que confere à música nacional a mesma dignidade da música européia. Na área das Bachianas brasileiras $n^{\circ}$ 4, o tema principal é a conhecida canção folclórica "ó mana deixa eu ir, ó mana eu vou só. Ó mana deixa eu ir pro sertão de Caicó”. A apreciação e o entendimento do espírito de sua obra possibilita a aproximação de um caráter incomum do povo brasileiro, latente na região Nordeste do país, repleta de sentimentos de bravura diante das misérias materiais.

Sua obra não se submete às classificações tradicionais, apenas às genéricas: "obras pianísticas, lieds, formas clássicas, e mais algumas outras, tão singulares, que não é possível subordiná-las a nenhum esquema, como as Bachianas e os Choros" (CARPEAuX, p. 358). A totalidade de sua obra, muito pouco conhecida no Brasil, é uma das mais respeitadas, entre as latino-americanas, na Europa. 
Junto à influência marcante de Stravinsky, houve e há no século XX outra influência decisiva: Arnold Schoenberg (1874-1951). Homem de personalidade intransigente, obteve pouco sucesso por causa das indigestas regras e sonoridades de suas peças. Ele abandonou a tonalidade e investiu no dodecafonismo. Sua obra, Variações para grande orquestra sobre o tema $B-A-C-H$ (nome do compositor Bach) é considerada a "arte da fuga" do dodecafonismo e está imersa no espírito schoenberguiano desagradável e hostil ao mundo (CARPEAUX, p. 376-381). Sua obra remete o ouvinte a uma atmosfera emancipada dos padrões musicais adaptados à linguagem escrita, que facilmente adaptou-se às necessidades mercantis da sociedade burguesa.

Essa imparidade também é percebida na obra de Adorno, ativo em seu protesto filosófico, literário e musical durante o período sangrento da Segunda Guerra Mundial. Em um dos seus seis estudos para quarteto de cordas, Sehr heftig, Adorno trabalha com tensões dissonantes no tema inicial, delineadas em um compasso binário composto, presentes em staccatos vivazes e dramáticos, tirados dos agudos e médios do violino. Logo após, vem o descanso, descanso no movimento do ritmo, não nas tensões atonais. O movimento, então, cresce num motivo semelhante ao tema, contudo, um pouco mais sombrio. Silencia e retorna ao tema inicial com um glissandro e termina com um acorde silencioso composto por dissonâncias.

John Cage (1912), uma das figuras marcantes da música concreta, inventou o piano preparado, "em cujas cordas se colocam pedaços de borracha ou de metal ou de madeira para produzir sons inéditos" (CARPEAUX, p. 390). Essa inovação revela que os avanços da tecnologia produtora de sons refinados não satisfizeram a curiosidade do ouvido humano.

As inovações dessas manifestações musicais não colocam a nova música em um lugar distinto da música convencional, pois, apesar de apresentar linguagens diferentes, foi preciso que a estrutura dessas fizessem-se racionalmente compreensíveis. O compositor, então, utiliza critérios da racionalidade para transmitir o conteúdo. Mesmo correndo o risco de sucumbir à armadilha da produção musical rentável, o compositor pode manifestar sua subjetividade que irá necessariamente expressar-se em uma relação dialética com os limites impostos ao conteúdo pela objetividade, que é o espírito de seu tempo. Por isso, "a medida da verdade social da música é dada pela contradição entre a sua substância, ligada à 
sua constituição imanente, e a sociedade, de que nasceu e em que está" (ADORNo, p. 133).

Essa relação dialética com a realidade vigente permite o diálogo entre elementos musicais de origens, etnias e estruturas diferentes, sem que haja um estilo de natureza "elevada". Compositores, como César Guerra-Peixe, fizeram instrumentos eruditos de origem européia, como o violino, entoar lamentos nordestinos e modais. Nesse diálogo, deve ser descartada a idéia de reconciliação ou aglutinação de elementos. O que ocorre, e deve ocorrer, é a pluralização de um conjunto sistematizado, no qual o sentido de cada elemento é salvo da idéia de fracasso ou da superação dele mesmo por outro elemento tido como melhor ou mais funcional.

Tais obras de inconformados homens carregam em si os traços de Melancolia I, do pintor Albrecht Dürer, evocando a desolação meditativa e descrente de um anjo diante dos instrumentos de medida científica (MATos, p. 70): esfera, régua, compasso e ampulheta. Sua dor e depressão convocam-no para uma nova viagem em torno, ao redor e dentro de si mesmo. Esse é o retrato dos homens de todos os tempos, almas penadas em seu próprio solo, um solo sempre estrangeiro. Mas houve um momento em que esse solo pertenceu ao homem? Adorno, nas entrelinhas de sua filosofia e de sua música, afirma que não, pois a vida não é vitória, é luta; a tonalidade e a atonalidade não são fórmulas, são relações; a cultura não é um sistema, mas expressões organizadas, diferenciadas e afins; e a liberdade não é um estado de espírito, mas uma conquista que não se submete a descansos ou trunfos, imersa nas tensões e dissonâncias incansáveis da vida.

A música, para muitos, só tem valor se funcionar como um instrumento de sedução, por meio do qual os tolos apreciam-na distraidamente e consideram-na divina, maravilhosa e encantadora. Por isso, a apreciação dos elementos diferentes da nova música permite o confronto do indivíduo reificado com o diferente, incomum e não mercantil. O diferente é o espelho onde todo indivíduo reconhece-se também como diferente e único, capaz de contemplar a massa social como um conjunto de pessoas bem mais interessantes que a cultura em que estão submersas. Esse conjunto pode tornar-se então o eternamente almejado reino da liberdade, onde acontece o livre jogo das faculdades individuais outrora reprimidas (MARCUSE, 1968). Nesse jogo, novas formas de realização e 
de descoberta do mundo são experimentadas, bem mais interessantes que a relação interesseira entre Polifemo e Ulisses.

\begin{abstract}
In this article the author intends to show how the myth of rationalism has been built by modern men on the expenses of Ulysses, a mythic heroic figure who destroys the Cyclopes Polifemo. This rational myth is present in the cultural industry, mainly in musical masterpieces. The author points out new music as an alternative for an aesthetic conception, which comprises the differences of nonprofitable values and characters that the cultural industries disregard and prejudge.
\end{abstract}

Key words: myth of rationalism, modern being, cultural industry, new music.

\title{
NOTAS
}

1. Em um dos relatos de um dos grupos indígenas brasileiros, há o da origem do dia e da noite: "ao transportarem um coco, certos índios ouviram de dentro dele ruídos estranhos e não resistiram à tentação de abri-lo, apesar de recomendações contrárias. De dentro do coco escapuliu então a escuridão da noite. Por piedade divina, a claridade lhes foi devolvida pela Aurora, mas com a determinação de que nunca mais haveria só claridade, como antes, mas alternância do dia e da noite." (ARRUDA, 1986, p. 20)

2. O mito de Édipo, por exemplo, é interpretado diferentemente por Freud, LeviStrauss e Foucault (RосHA, p. 49).

3. Augusto Comte, filósofo francês do século XIX, foi fundador do positivismo. Definiu que a maturidade do ser humano é alcançada mediante o abandono de todas as formas míticas e religiosas. O fato positivo é possível de ser medido e controlado pela experimentação. Essa abordagem filosófica reduziu a interpretação do real à visão científica, gerando o mito da cientificidade. Esse mito é gerador de outros mitos, como o mito do progresso, que culminou na tecnocracia (ARRUDA, 1986, p. 26).

4. Guido Antônio de Almeida, tradutor da obra Dialektik der Aufklarung Philosophische Fragmente, em 1985, traduz o termo Aufklarung por Esclarecimento e não por Iluminismo, como é encontrado em outras traduções. Ele justifica esse proceder, afirmando que esclarecimento remete a um significado mais amplo, que é "o processo pelo qual, ao longo da história, os homens se libertam das potências míticas da natureza, ou seja, o processo de racionalização que prossegue na filosofia e na ciência" (ADORNo e HoRKHEIMER, p. 8). Ao contrário de pensadores iluministas como Kant, que exaltou o 
Esclarecimento com a máxima Sapere Aude (ouse saber), afirmando que este é a libertação do estado de submissão do intelecto a outrem, Adorno e Horkheimer afirmam que a origem do esclarecimento encontra-se no próprio mito e atualmente está presente na ciência positiva, que é a mitologização do esclarecimento, no qual o pretensioso domínio racionalista da natureza pelo homem pode levá-lo paradoxalmente à sua própria irracionalidade. Sendo assim, o significado do termo não pode resumir-se à compreensão que se tem do período das luzes, como é conhecido o século XVIII, mas denota e aponta com desilusão o seu pretenso otimismo.

5. Utilizado pela primeira vez por Pitágoras e/ou pelos pitagóricos, o termo mônada, proveniente do grego (monas), significa unidade, elemento mínimo e indivisível do real. Para Leibniz, são as mônadas os verdadeiros átomos da natureza. São distintas entre si, existem sem interação dentro de uma hierarquia cuja base são as percepções obscuras e inconscientes e os últimos estágios são as percepções claras, distintas e Deus, a Mônada Suprema. Não possuem portas ou janelas, ou seja, não se comunicam e coexistem em uma harmonia preestabelecida (Logos, Enciclopédia Luso-Brasileira de Filosofia, v. III, p. 934).

6. Os modos são fórmulas de escalas que os gregos usaram primeiramente, baseados na escala pitagórica, e depois modificados e adaptados pelos músicos medievais. "[...] baseavam-se no que são hoje as notas brancas do piano, com certas diferenças de afinação. Por volta do século II d.C., os gregos estavam usando a escala pitagórica de sete maneiras diferentes. Estas foram adaptadas no século IV por Santo Ambrósio, bispo de Milão, para uso esclesiástico em quatro modos, mais tarde conhecidos como modos autênticos. No século VI, São Gregório Magno aperfeiçoou os modos ambrosianos e acrescentou-lhes mais quatro, os quais receberam a designação de modos plagais. Esses oito modos são os chamados modos eclesiásticos. Finalmente, no século XVI, o monge suíço Henrique de Glarus (Henricus Glareanus) definiu 12 modos e atribui-lhes nomes gregos, embora muitas de suas identificações com os modos gregos fossem incorretas. Alguns dos 12 modos eram de escasso uso prático, mas com o desenvolvimento de Glareanus (o jônico e o eólio) foram considerados os mais adequados à harmonia e passaram a ser conhecidos, do século XVII em diante, respectivamente, como escala maior e escala menor, nas quais a grande maioria da música se baseia desde então. Os modos medievais permanecem em uso no cantochão e em alguma música folclórica”. (Dicionário de música Zahar, 1985, p. 242).

7. O termo "música popular", utilizado neste texto, não faz alusão a estilos como a MPB e outros provenientes da cultura de diversos países, e, sim, à produção musical comercial e industrializada, cuja estrutura procede do padrão da música pop estadunidense (Nota do autor). 
8. Padrão, protótipo, norma, medida, qualidade. No contexto globalizado da indústria cultural, também pode ser entendido como a base regulamentadora e legalizadora do sistema capitalista, pois provoca, nos consumidores da arte comercial, uma sensação de adequação social (Adorno, p. 119).

9. O dodecafonismo constitui-se por uma estrutura de 12 sons da escala cromática colocados em série (serialismo). Foi empregado pela primeira vez por Arnold Schoenberg, em 1923. (Dicionário de Música Zahar, 1985, p. 105 e 347).

10. Uns dos exemplos clássicos de horror que até hoje choca o mundo inteiro foram os quatro campos de concentração de Auschwitz, na Polônia, durante a Segunda Guerra Mundial, em 1940. Nesses campos foram sacrificados entre dois e três milhões de judeus em câmaras de gás e fornos de incineração (Enciclopédia Delta Larousse, v. II, 1970, p. 605).

11. Teoria do mecanismo psíquico proposta por Sigmund Freud (1856-1939). O id é o conjunto dos impulsos inconscientes da libido; O superego é a consciência moral e o ego é o intercâmbio entre os dois (Reale, p. 928).

\section{REFERÊNCIAS}

ADORNO, T. Idéias para a sociologia da música. Revista Teoria e prática. São Paulo, Teoria e Prática Editora, 1968.

. In der Aufkkassung Neuer Musik. In: Improptus. Tradução de Flávio R. Kothe. Frankfurt: Suhrkamp, 1968.

Erziehung nac Auschwitz. In: Stichworte; krtische Modelle 2.

Tradução de Aldo Onesti. Frankfurt: Suhrkamp, 1974.

. HORKHEIMER, M. Dialética do esclarecimento. Tradução de Guido Antonio de Almeida. Rio de Janeiro: Jorge Zahar, 1985.

SIMPSON,G. On popular music. In: HORKHEIMER, M. Studies in philosophy and social science. Tradução de Flavio R. Kothe. Nova York: Institute of Social Research, 1941.

ARRUDA, M.; MARTINS, M. Filosofando. São Paulo: Moderna, 1986.

CARPEAUX, O. M. Uma nova história da música. Rio de Janeiro: Ediouro, 1999.

COELHO, T. O que é indústria cultural. 17. ed. São Paulo: Editora Brasiliense. (Coleção Primeiros Passos).

COHN, G. (Org) Theodor W. Adorno - sociologia. São Paulo: Editora Ática, 1986. 
GRANDE ENCICLOPÉDIA DELTA LAROUSSE, v. II, Rio de Janeiro: Editora Delta, 1970.

HOMERO, Odisséia. Rio de Janeiro: Cultrix, 1968.

ISAACS, M. E. Dicionário de música Zahar. Rio de Janeiro: Zahar Editores, 1985.

MATOS, O. Filosofia, a polifonia da razão: filosofia e educação. São Paulo: Scipione, 1997.

MARCUSE, H. Eros e civilização. São Paulo: Zahar, 1968.

REALE, G. A D. História da filosofia, 2. ed. v. III. São Paulo: Paulus, 1990.

SOCIEDADE CIENTIIFICA DA UNIVERSIDADE CATÓLICA PORTUGUESA. LOGOS: Enciclopédia luso-brasileira. Lisboa;São Paulo: Editorial Verbo, 1989. 
